Abstracta Iranica Abstracta Iranica

Revue bibliographique pour le domaine irano-aryen

Volume 25 | 2004

Comptes rendus des publications de 2002

\title{
Tamadon / On Civilization. Published in the series of «Blätter für Kultur und Gesellschaft » (No. 1), Münster, 2002, $144 \mathrm{p}$.
}

\section{Rédaction}

\section{(2) OpenEdition}

Journals

Édition électronique

URL : http://journals.openedition.org/abstractairanica/5125

DOI : 10.4000/abstractairanica.5125

ISSN : 1961-960X

Éditeur :

CNRS (UMR 7528 Mondes iraniens et indiens), Éditions de l'IFRI

\section{Édition imprimée}

Date de publication : 15 mai 2004

ISSN : 0240-8910

Référence électronique

Rédaction, «Tamadon / On Civilization. Published in the series of «Blätter für Kultur und Gesellschaft » (No. 1), Münster, 2002, 144 p. », Abstracta Iranica [En ligne], Volume 25| 2004, document 312, mis en ligne le 15 mars 2006, consulté le 25 septembre 2020. URL : http://journals.openedition.org/ abstractairanica/5125; DOI : https://doi.org/10.4000/abstractairanica.5125

Ce document a été généré automatiquement le 25 septembre 2020.

Tous droits réservés 


\section{Tamadon / On Civilization. Published in the series of « Blätter für Kultur und Gesellschaft » (No. 1), Münster, 2002, 144 p.}

\section{Rédaction}

1 This is a contribution to the contemporary discussion on the role and place of civilizations in the world of today. After an etymological survey of the word Tamadon in Persian, the author has devoted two other chapters to the theory of the clash of civilizations and the future of the same. Not only the theory of Samuel P. Huntington, but also a number of views in favour of and against this theory are critically discussed here. Although the author criticizes Huntington's approach, from a different point of view he clearly shows that he is in favour of a civilizational approach. He thinks that the world is divided into different civilizations, which at the same time have many things in common. The existence of various civilizations does not necessarily lead to a clash between them; it is a source of enrichment of human culture. Therefore they are even able to develop a peaceful coexistence.

2 The last part of the book deals with the theory and views of Fernand Braudel presented in his famous book called A History of Civilizations.

\section{INDEX}

Thèmes : 12.1. Iran

nompropre Samuel P. Huntington, Fernand Braudel 


\section{AUTEURS}

\section{RÉDACTION}

Directeur de la revue et secrétariats (Paris et Téhéran) 